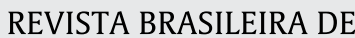

\section{Diversity and spatio-temporal variation of Anopheles (Diptera: Culicidae) before and after the construction of the Jirau hydroelectric plant, state of Rondônia, Brazil}

\author{
Francisco Augusto da Silva Ferreira ${ }^{*}$ (D), Fábio Medeiros da Costa $^{1}$ (D), \\ Gervilane Ribeiro de Lima $^{2}$ (D), Rosemary Aparecida Roque ${ }^{2}$ (D), \\ Vania da Costa Ferreira ${ }^{3}$ (D), Veríssimo Alves dos Santos Neto $^{3}$ (D), \\ Thais Melo Benchimol ${ }^{4}$ (D), Vera MargareteScarpassa ${ }^{5}$ (D), Wanderli PedroTadei ${ }^{2 \dagger}$ (i)
}

\author{
'Instituto Nacional de Pesquisas da Amazônia, Programa de Pós-Graduação em Entomologia, Manaus, AM, Brasil. \\ ${ }_{2}^{2}$ Instituto Nacional de Pesquisas da Amazônia, Laboratório de Malária e Dengue, Coordenação de Sociedade, Ambiente e Saúde, \\ Manaus, AM, Brasil. \\ ${ }^{3}$ Energia Sustentável do Brasil, Porto Velho, RO, Brasil. \\ ${ }^{4}$ Instituto Nacional de Pesquisas da Amazônia, Programa de Pós-Graduação em Genética, Conservação e Biologia Evolutiva,, Manaus, \\ AM, Brasil. \\ Instituto Nacional de Pesquisas da Amazônia, Laboratório de Genética de Populações e Evolução de Mosquitos Vetores, Coordenação \\ de Biodiversidade, Manaus, AM, Brasil.
}

\section{A R T I C L E I N F O}

\section{Article history:}

Received 18 October 2020

Accepted 19 April 2021

Available online 28 May 2021

Associate Editor: Gustavo Graciolli

\section{Keywords:}

Environmental changes

Malaria

Western Amazonia

\begin{abstract}
A B S T R A C T
The objective of this study was to evaluate the effect of the construction of the Jirau hydroelectric plant on the anopheline species, in Porto Velho, Rondônia, Brazil. For this, sampling was carried out in 23 locations in the pre (2004) and 23 after construction (2018) phases in the hydroelectric dam's coverage area, performed by human landing catch between 6:00 pm and 10:00 pm. We found 14 anopheline species. In the pre-construction phase, An. darlingi (73\%) was the most abundant and after construction An. braziliensis (31.5\%) was the most abundant. The T test indicated that there were no differences in the indexes - diversity ( $\mathrm{H}^{\text {')}}$, richness (Sjack 1 ), equitability $(J)$ and dominance $(d)$ of anophelines species - evaluated between the phases $(\mathrm{p}>0.05)$. The spatio-temporal distribution of $A n$. darlingi proved to be wide, with the highest density values observed in $\operatorname{March}\left(\bar{x}_{1}=27.1\right)$ in the pre-construction phase and in the months of May $\left(\bar{x}_{w}=4\right)$ and July $\left(\bar{x}_{w}=3.1\right)$, post-construction. Differences in hematophagic activity peaks were observed between species and between phases. According to the data obtained in this study, the construction of the hydroelectric plant had little influence on the composition of anopheline species, however changes were observed in the spatio-temporal distribution of the An. darlingiand in the pattern of hematophagic activity of the species, which directly influenced the dynamics of malaria in the region.
\end{abstract}

\section{Introduction}

After the acceleration of the industrialization process, the economy started to explore the energy potential in water resources to meet the national demand (Sadorsky, 2013; Li and Lin, 2015). Therefore, during the 70s the construction of hydroelectric plants began in the Brazilian Amazon region, being Coaracy Nunes in the state of Amapá, Curuá-Una and Tucuruí in the state of Pará and Balbina in Amazonas, in addition to these, the Brokopondo in Suriname. The region has the largest hydrographic basin in the world and has a high potential for energy production (Fearnside, 2015; Tolmasquim, 2016).

\footnotetext{
* Corresponding author.

E-mail: fcoaugusto.bio@gmail.com (F.A.S. Ferreira).

$\dagger$ In Memorian
}

The installation of hydroelectric projects implies changes in the environment with possible impacts on flora and fauna (Odinetz-Collart, 1987; von Sperling, 2012). In addition, another relevant aspect is the increase in the incidence of pathogen transmitted by insect vectors, of water transmission and others related to migration (Tadei et al., 2017). In this context, diseases such as arboviruses, schistosomiasis, filariasis and malaria were frequently registered in areas covered by hydroelectric plants in the Brazilian Amazon (Junk and Nunes de Mello, 1987, 1990; Couto, 1999; Sanchez-Ribas et al., 2012).

The malaria is considered a serious public health problem worldwide and in Brazil 99.8\% of cases are registered in the Brazilian Amazon region, where approximately 42.5 million people live in risk areas 
(Oliveira-Ferreira et al., 2010; Ferreira and Castro, 2016; WHO, 2019). The maintenance of this disease is directly associated with human action in the environment, characterized by disordered occupations in urban and peri-urban spaces, deforestation, irrigation projects, construction of fish farming tanks, exploration of fossil fuels, minerals and natural gas and construction of highways, greatly contributing to the exposure of man to the vector and consequently to the pathogen transmission (Tadei et al., 1988, 1998, 2017; Padilha et al., 2019; Chaves et al., 2020). In addition, climatic factors can favor transmission, such as el niño and la niña and global climate changes that promote variations in precipitation, humidity, temperature and level of rivers in the region (Wolfarth-Couto et al., 2019).

According to Tadei et al. (2017), environmental changes in malaria endemic regions result in changes in the degree of disease incidence. This fact is directly associated with the increase in the density of Anopheles darlingi Root, 1926, the main vector of human malaria in Brazil. This mosquito can trigger outbreaks of the disease even in low density situations due to the anthropophilic behavior (Tadei et al., 1993; Tadei and Dutary-Thatcher, 2000; Sallum et al., 2020). In addition, other species may act in the transmission of Plasmodium in the region, among which are Anopheles aquasalis Curry, 1932, Anopheles albitarsis s.l Lynch Arribálzaga, 1878, Anopheles triannulatus (Neiva and Pinto, 1922), Anopheles nuneztovari Galbadon, 1940 and Anopheles oswaldoi (Peryassú, 1922) (Tadei et al., 1993; Deane, 1986).

Another relevant factor from the epidemiological point of view in areas covered by hydroelectric plants is the increase in the migratory flow of human populations attracted by employment opportunities, a fact observed in hydroelectric dams in the state of Pará - Tucuruí and Belo Monte - in addition to the Santo Antônio and Jirau hydroelectric dams in the state of Rondônia (Fearnside, 1999, 2001; Barreto et al., 2011). In general, hydroelectric projects can offer risks regarding the increase in the number of malaria cases, because in addition to perening anophelines breeding sites on the banks of reservoirs, a fact that contributes to maintaining high densities of vectors throughout the year, human populations often come from non-endemic regions and have greater susceptibility to infection by Plasmodium species, when compared to Amazonian populations (Katsuragawa et al., 2009). In addition, the entry of oligosymptomatic individuals in these areas is also emphasized, introducing the etiological agent and favoring outbreaks and maintenance of malaria (Tadei et al., 1983, 1998).

The Brazilian environmental legislation, aiming to mitigate these impacts, determined that the enterprises subject to environmental licensing in the Amazon must comply with the provisions of Ordinance of the Ministry of Health No. 47 of 12/29/2006 (MS, 2006), this being then revoked by Ordinance of the Ministry of Health No. 01 of 01/13/2014 (MS, 2014). This legal provision obliges enterprises to implement an Action Plan for Malaria Control - PACM, in line with the National Malaria Prevention and Control Program - PNCM (MS, 2003), aimed at workers' health and the communities located in the area covered by these projects. PACMs consist of protocols of intentions where enterprises are required to adopt exclusive mitigation and compensatory measures for the control of malaria with the municipalities in the coverage area where they are installed. In this way, public-private partnerships are established where both (municipality and entrepreneur) have defined roles in the responsibilities and commitments to the reduction of malaria (MS, 2014). The main result of the implementation of PACMs in Porto Velho was that the municipality managed to reduce the number of cases of the disease by $83 \%$, a fact that led to the evolution of the level of high risk of transmission in 2010 to low risk since 2015 (SEMUSA-PMPV, 2017).

Some species of mosquitoes can be favored from the environmental changes resulting from the construction of hydroelectric plants, as the artificial lake becomes a breeding ground for several culicids as observed in the Tucuruí, Balbina, Samuel, Itaipu and Porto Primavera hydroelectric plants, where there was a significant increase in frequency of anophelines in the post-construction stages of the project (Tadei et al., 1983; Osório-Quintero et al., 1996; Tadei et al., 1998; Paula and Gomes, 2007; Silva et al., 2010; Paula et al., 2012; Rodrigues et al., 2017; Pires et al., 2019; Rêgo et al., 2020). These mosquitoes in natural conditions develop in breeding sites consisting of black water floodplain forests (igapó), backwaters of rivers and streams (Arcos et al., 2018). However, adaptations to anthropized environments have enabled proliferation of anophelines in artificial breeding sites, such as fish ponds, pottery pools and hydroelectric ponds (Guimarães et al., 2004; Ferreira et al., 2015).

The area covered by hydroelectric dams on the Madeira River in Rondônia has been the subject of studies with the objective of understanding aspects related to the bioecology of anopheline species, with high density records by An. darlingi (Cruz et al., 2009; Morais et al., 2012; Gil et al., 2015; Rodrigues et al., 2017). The study of the diversity and distribution of anophelines in endemic areas that have undergone some process of environmental change is of great epidemiological value, as there are variable and specific conditions for each location, considering the complexity of the Amazon ecosystem (Tadei et al., 1983).

Therefore, the objective of this study was to analyze aspects related to diversity, spatial and temporal distribution and behavioral patterns of anophelines during the pre and post-construction phases of the Jirau hydroelectric plant, and the possible epidemiological implications.

\section{Methods}

\section{Study area}

The state of Rondônia has an important position in relation to phytogeographic aspects, being located in the center of the Amazon basin, in a transition region between the geomorphological domain of Central Brazil and the Amazon geomorphological domain. The municipality of Porto Velho, the capital of state, is located in the north of the state, with a territorial area of $34.082 .37 \mathrm{~km}^{2}$ and a population of 539.354 inhabitants, with a demographic density of 12.57 inhabitants $/ \mathrm{km}^{2}$ and its rural population is 37.794 (IBGE, 2019). Porto Velho's climate is of the Am type, according to the Köppen classification, consisting of a humid tropical climate, with a dry media capacity of less than $10 \mathrm{~mm}$ and an annual media capacity of $2.355 \mathrm{~mm}$. The vegetation of the area is selected as an open tropical forest, with a predominance of red-yellow latosol. The Jirau hydroelectric plant was a work of the PAC - Growth Acceleration Program of the Federal Government of Brazil. The dam is located on the axis where the Ilha do Padre was located, $120 \mathrm{~km}$ away from the headquarters of the municipality of Porto Velho, with formation of a flooded area in 2013 and estimated useful life of more than 50 years, with dynamic level, that is, the level of the lake follows the dynamics of the flows of rivers in the Amazon. The production of energy occurs through the use of 50 turbines inserted in the waterway of the Madeira River, with a reservoir of $361.6 \mathrm{~km}^{2}$ and an installed capacity to generate $3.750 \mathrm{MW}$, sufficient to supply 10 million homes (ESBR, 2020).

Sampling was carried out at different times covering the preconstruction and post-construction phases of the hydroelectric plant. In the pre-construction phase, monthly collections were carried out from January to August 2004, in 23 locations and after construction also in 23 locations from March to October 2018 (Fig. 1) (license number SISBIO $n^{\circ} 58855-1$ ). The section studied comprises the districts of Jaci Paraná and Abunã, including the Abunã ferry, performing a linear distance of $138 \mathrm{~km}$. The area studied comprises areas close to the main bed of the Madeira River and points located in vicinal areas located on the right bank of BR 364 Highway. The criterion used for the 


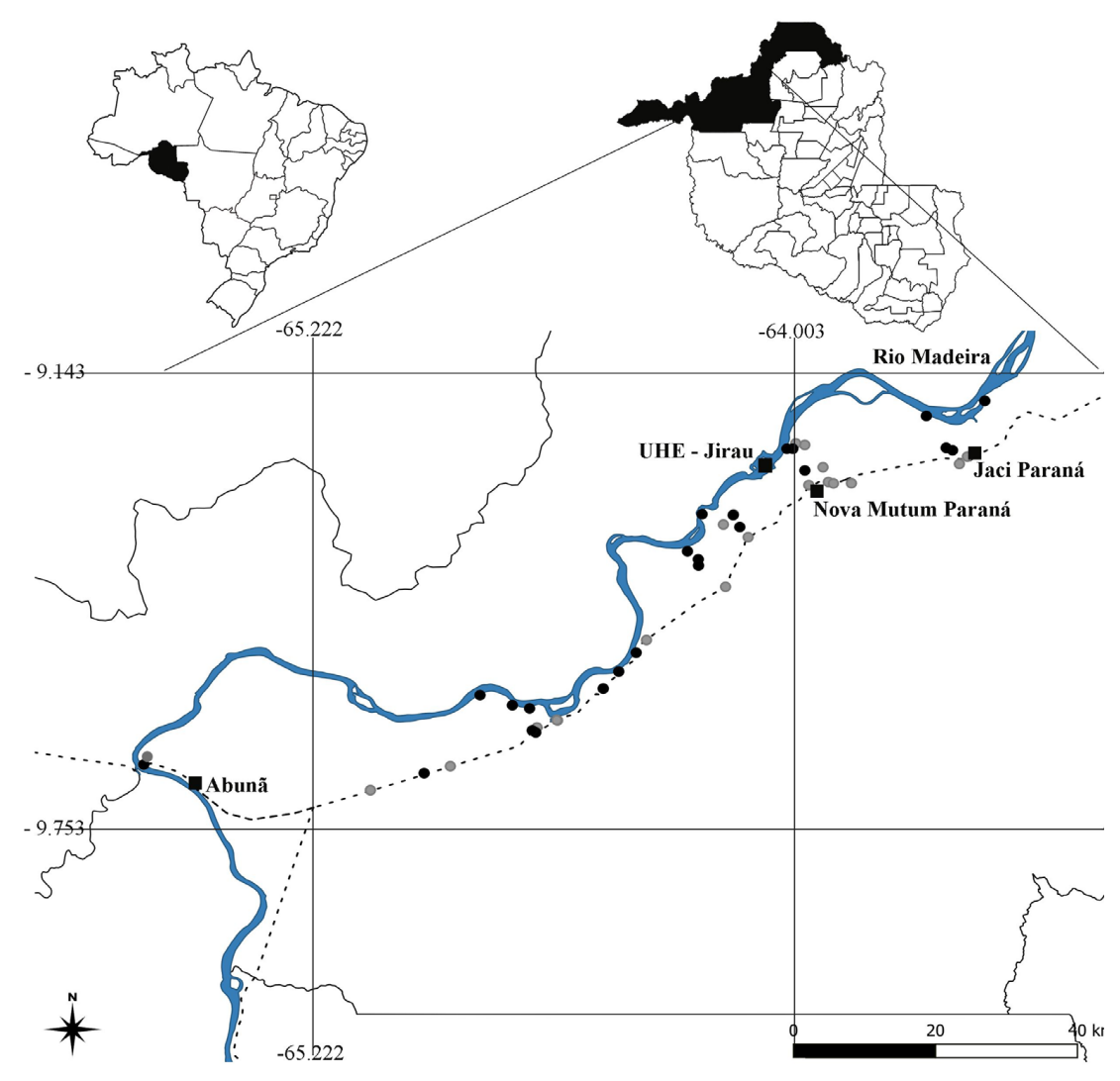

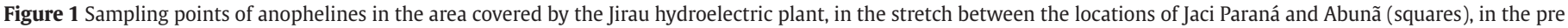
(black) and post-construction (gray) phases.

selection of the collection points was the presence of human dwellings in situations of risk for malaria that were in the area covered by the Jirau hydroelectric plant.

\section{Sampling of mosquitoes}

The collections were performed by three collectors in a non-rotated performed by Human Lading Catch (HCL) (INPA Ethics Committee $\mathrm{N}^{\circ} 3.474 .088$ ) in the peridomiciliary area from human dwelling, with an effort of 344 collection hours in each evaluated phase. In the pre and post-construction phases, sampling was carried out between $6: 00 \mathrm{pm}$ and 10:00 pm. In this way, mosquitoes attracted by the human odor (cairomonium) were aspirated and transferred to paraffin cups with the aid of Castro's captor, and in followed transported to the Malaria and Dengue Laboratory, of the Instituto Nacional de Pesquisas da Amazônia - INPA. The capture activities were conducted as determined by the Ministry of Health of Brazil (MS, 2019), so everyone involved was wearing personal protective equipment consisting of black socks, long jeans, long shirts, closed shoes and a hat.

At the laboratory, the specimens were killed in a freezer $\left(-20^{\circ} \mathrm{C}\right)$, labeled and stored for later identification. The identification was carried out with the aid of keys proposed by Goham et al. (1967), Consoli and Lourenço de Oliveira (1994) and Faran and Lintichum (1981). Due to An. triannulatus, An. albitarsis, An. oswaldoiand An. nuneztovari to represent species complexes, in this study these species were called sensu lato. The specimens are deposited in the collection of the Laboratório de Malária e Dengue; later, a part them will be sent to the Collection of Invertebrates of the Instituto Nacional de Pesquisas da Amazônia, INPA.

\section{Data analysis}

The relative abundance (\%) of anopheline species was calculated for each phase studied. The punctual data of An. darlingi in the sampled area during the pre and post-construction phases were used to evaluate the spatial distribution of this species in the section between the districts of Jaci Paraná (BR 364 Federal Highway, km 799) and Abunã (BR 364 Federal Highway, km 937). For that, a heat map was obtained using the Kernel method with the aid of the Qgis software v.3.4.12. In addition, Shannon's diversity indexes $\left(\mathrm{H}^{\prime}\right)$, richness (1st order Sjack), Pilou equitability $(J)$ and Berger-Parker dominance ( $d$ ) were calculated using the software DivEs - Diversidade de Espécies ® v. 4.15 (available in https://dives. ebras.bio.br/), for both phases (pre and post-construction) (Rodrigues 2017). In order to assess possible changes, the values of these indices were compared using the T test $(\mathrm{p}<0.05)$.

It was also evaluated the pattern of greater hematophagic activity of the most abundant species in the studied phases. We consider the following intervals: from 6:00 pm to 7:00 pm, 7:00 pm to 8:00 pm, 8:00 pm to 9:00 pm, and 9:00 p.m. to 10:00 p.m. in the pre and postconstruction phases. The specimens were organized in paraffin cups that were properly labeled, with information on the time interval for capture and location. The glasses were changed every 30 minutes, for a total time of 4 hours.

In order to assess the temporal distribution of the species, density was calculated using the Williams average $\left(\bar{x}_{\mathrm{w}}\right)$, used to demonstrate seasonal patterns and obtained using the following formula: $\bar{x}_{\mathrm{w}}=$ [antilog $\left(\sum \log (n+1) / N\right]-1$, where: $\bar{x}_{\mathrm{w}}$ : Williams average; n: number of individuals caught in the month; $\mathrm{N}$ : total number of months sampled (Forattini, 2002). 
The monthly averages of temperature $\left({ }^{\circ} \mathrm{C}\right)$, rainfall $(\mathrm{mm})$ and relative humidity (R. H.\%) were obtained from the Instituto Nacional de Meteorologia of Brazil (INMET) and fluviometric data, available on the website of the Agência Nacional de Águas of Brazil (ANA). Malaria data were obtained through SIVEP / SVS (Sistema de Informação de Vigilância Epidemiológica of Secretaria de Vigilância em Saúde - SVS of Brazil) from the following locations in the area covered by the Jirau hydroelectric plant: Abunã and Jaci Paraná. In order to assess the possible relationships between Anopheles species, environmental variables and the number of cases of malaria, they were subjected to canonical correlation analysis (CCA), for each sampled phase. All statistical analyzes were calculated with the aid of the PAST v. 2.17 (PAleontological Statistics) software (available in https://palaeo-electronica.org/2001_1/past/issue1_01.htm).

\section{Results}

\section{Species composition}

The anopheline fauna found in the area covered by the Jirau hydroelectric plant, considering the pre- and post-construction phases, was composed of 14 species, distributed in the subgenera Anopheles and Nyssorhynchus. In the pre-construction phase, 12 species were found and $A n$. darlingi was the most abundant (73\%), followed by An. albitarsis (12.9\%). The least abundant were An. rangeli and An. mattogrossensis (both with $0.03 \%$ ) (Table 1). In the post-construction phase, An. braziliensis (31.5\%) was the most abundant species out of the total of 13 species found, followed by An. darlingi (28\%) and the least abundant were An. rangeli and An. mediopunctatus (both with $0.05 \%$ ).

\section{Ecological indexes}

The diversity ( $\mathrm{H}$ ') of anophelines in the pre-construction phase of the hydroelectric plant varied between 0.5719 and 1.5294 and the values of richness (Sjack 1) between 3 and 10, with an average of 6.875 . The equitability values $\left(J^{\prime}\right)$ varied between 0.2213 and 0.9649 , while dominance $(d)$ varied between 0.4083 and 0.92 . According to the values of dominance (d), An. darlingi was dominant in all samples.

In the post-construction phase, the diversity values $(\mathrm{H}$ ') varied between 0.7133 and 2.2153 . The values of richness (Sjack 1 ) varied between 4 and 12, with an average of 6.62, slightly lower than that found in the pre-construction phase, while those of equitability $(J)$ varied between 0.3072 and 0.7629 . Considering the dominance data (d), An. darlingi was dominant in 4 of the 8 samplings performed and in the other months the dominant species were: An. braziliensis, An. nuneztovari and An. albitarsis. The T test revealed that there were no significant differences $(\mathrm{p}>0.05$ ) between the variables - diversity, richness, equitability and dominance - between the pre and postconstruction phases of the Jirau hydroelectric plant. However, changes in dominance were observed, since in the pre-construction phase An. darlingi was the dominant species in all samples, while in the post-construction phase there was alternation of dominance between An. darlingi and other Anopheles species.

\section{Spatio-temporal distribution of Anopheles darlingi}

In the area covered by the Jirau hydroelectric plant, it was possible to sample the homes around houses of different characteristics: $2 \mathrm{a}$ house located on a site in a forest area; $2 b$ - wooden house in varzea area with straw roof; $2 c$ - Brick house in a village with clay roof and $2 \mathrm{~d}$ - wooden house with asbestos tile. The difference observed in the abundance of An. darlingibetween the phases was reflected in the heat map obtained from the Kernel method. Differences were observed in the spatial distribution of An. darlingi where in the pre-construction phase a high abundance of this species was observed along the stretch between Jaci Paraná and Mutum Paraná (Fig. 2e), especially in the vicinity of the localities of Jaci Paraná. On the other hand, in the post-construction phase, a reduction in areas of high abundance was observed, registering only in the region of near the Jirau hydroelectric plant (Fig. 2f).

According to the Williams average $\left(\bar{x}_{\mathrm{w}}\right)$ obtained in the preconstruction phase, An. darlingi showed a higher density in March $\left(\bar{x}_{\mathrm{W}}=27.1\right)$, with a sharp drop in the subsequent months, thus presenting a unimodal pattern of temporal distribution. The averages observed for An. albitarsis and An. braziliensis did not show great variation, remaining low during the sampled phase (Fig. 3a). A bimodal pattern of temporal distribution of An. darlingiwas observed in the post-construction phase, in May $(\bar{x} \mathrm{~W}=4)$ and July ( $\bar{x} \mathrm{~W}=3.1)$, respectively. The highest values of density of An. nuneztovariand An. braziliensis were observed in March $(\bar{x} \mathrm{~W}=0.8)$ and June $(\bar{x} \mathrm{~W}=1.18)$, respectively. It is noteworthy that the

Table 1

Relative abundance (\%) of anophelines collected in the pre (2004) and post construction (2018) phases of the Jirau hydroelectric plant, in Rondônia, Brazil.

\begin{tabular}{|c|c|c|c|c|c|}
\hline \multirow{2}{*}{ Subgenera } & \multirow{2}{*}{ Species } & \multicolumn{2}{|c|}{ Pre } & \multicolumn{2}{|c|}{ Post } \\
\hline & & $\mathbf{N}$ & R. A (\%)* & $\mathbf{N}$ & R. A (\%) \\
\hline \multirow[t]{4}{*}{ Anopheles } & Anopheles peryassui Dyar \& Knab, 1908 & 35 & 1.35 & 6 & 0.35 \\
\hline & Anopheles mattogrossensis Lutz \& Neiva, 1911 & 1 & 0.03 & 11 & 0.5 \\
\hline & Anopheles mediopunctatus (Lutz,1903) & 8 & 0.30 & 1 & 0.05 \\
\hline & Anopheles minor da Costa Lima, 1929 & - & - & 14 & 0.9 \\
\hline \multirow[t]{12}{*}{ Nyssorhynchus } & Anopheles albitarsis s.l Lynch Arribálzaga, 1878 & 337 & 12.9 & 135 & 9 \\
\hline & Anopheles argyritarsis Robineau-Desvoidy, 1827 & - & - & 2 & 0.15 \\
\hline & Anopheles benarrochi Gabaldon, Cova \& Lopez, 1941 & 2 & 0.07 & - & - \\
\hline & Anopheles braziliensis (Chagas, 1907) & 241 & 9.2 & 476 & 31.5 \\
\hline & Anopheles darlingi Root, 1926 & 1897 & 73 & 426 & 28 \\
\hline & Anopheles evansae (Brèthes 1926) & 4 & 0.15 & 32 & 2.1 \\
\hline & Anopheles nuneztovari Gabaldon, 1940 & 14 & 0.55 & 254 & 17 \\
\hline & Anopheles oswaldoi s.l (Peryassú 1922) & 9 & 0.35 & 6 & 0.4 \\
\hline & Anopheles rangeli Gabaldon, Cova-Garcia \& Lopez, 1940 & 1 & 0.03 & 1 & 0.05 \\
\hline & Anopheles triannulatus s.I (Neiva \& Pinto, 1922) & 43 & 2 & 141 & 9.5 \\
\hline & Anopheles sp. & 2 & 0.07 & 8 & 0.5 \\
\hline & Total & 2594 & 100 & 1513 & 100 \\
\hline
\end{tabular}



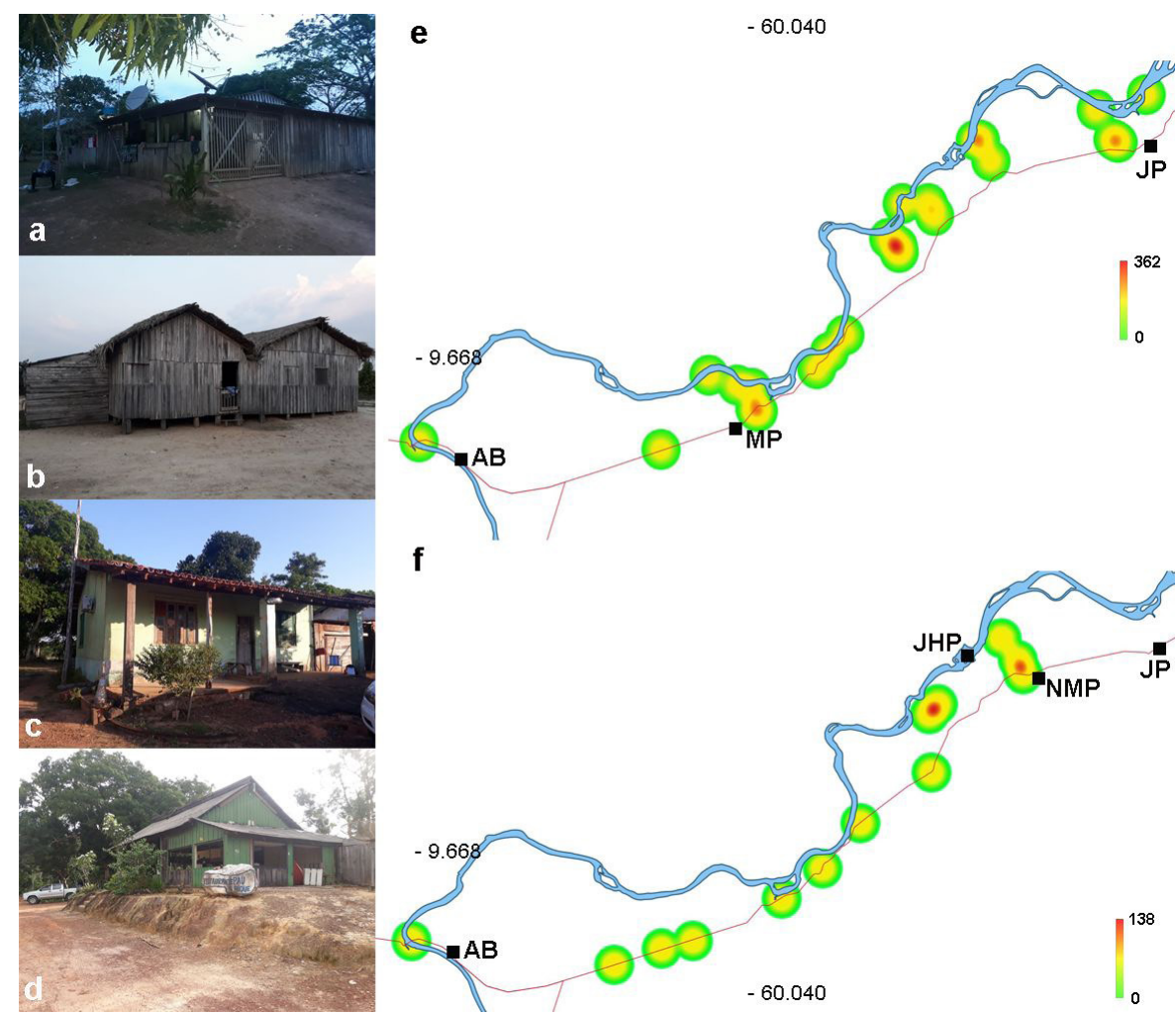

Figure 2 Housing types (a-d) spatial variation of Anopheles darlingi before (e) and after (f) the construction of the Jirau hydroelectric plant, in Rondônia, Brazil. Subtitle: AB Abunã; JHP - Jirau Hydroeletric Plant; JP - Jaci Paraná; NMP - Nova Mutum Paraná.
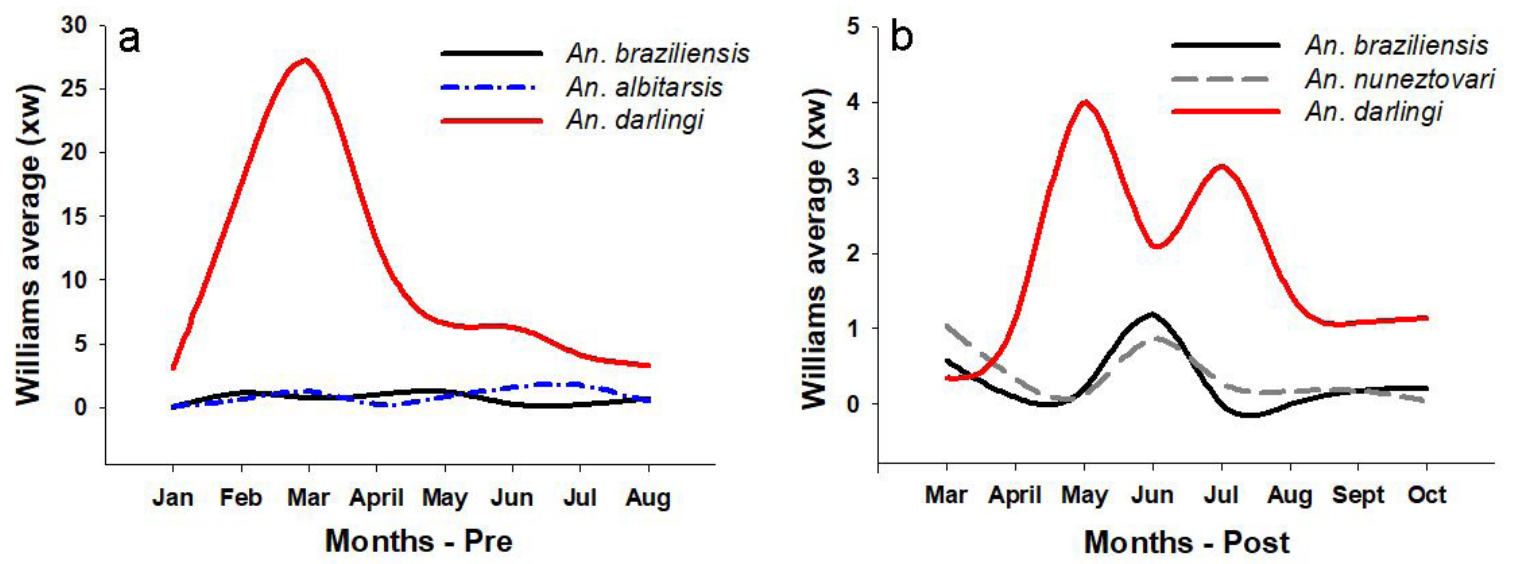

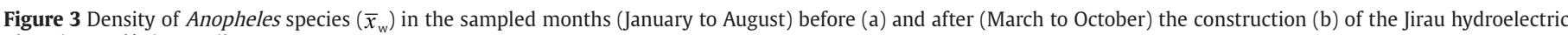
plant, in Rondônia, Brazil.

average Williams $\left(\bar{x}_{\mathrm{w}}\right)$ of the species were lower than those found in the pre-construction phase of the Jirau hydroelectric plant (Fig. 3b).

\section{Patterns of hematophagic activity}

In the pre-construction phase of the hydroelectric plant, it was observed that the interval of greatest hematophagic activity was between 7:00 pm and 8:00 pm. The hematophagic activity of An. darlingi was intense in all the hourly intervals analyzed, mainly between 7:00 pm and 8:00 pm, in which $50.3 \%$ of the individuals of this species were observed, in this interval the peak of activity was observed for the other species evaluated (An. albitarsis - 41.5\%, An. braziliensis - 57.6\%), except An. peryassui, greater between 6:00 pm and $7 \mathrm{pm}$. After this interval, between 9:00 pm and 10:00 pm, a decrease in the hematophagic activity of all analyzed species was observed (Fig. 4a). In the post-construction phase, it was observed that the peak of greater hematophagic activity was between $6: 00 \mathrm{pm}$ and 7:00 pm, observed pattern for An. darlingi (52.3\%), An. albitarsis (80.7\%) and An. nuneztovari (74\%). This pattern was different from that observed for An. braziliensis and An. triannulatus, both were more frequent in the interval between 7:00 pm and 8:00 pm (58.8\% and 78.7\%, respectively). After 9:00 pm, a drop in hematophagic activity was observed for all analyzed species (Fig. $4 \mathrm{~b}$ ).

\section{Environmental characteristics and species of Anopheles}

In the pre-construction phase, the temperature values $\left({ }^{\circ} \mathrm{C}\right)$ varied between 14.3 and 35.4, the relative humidity (\%) varied between 71 and 85 while the precipitation $(\mathrm{mm})$ between 7.4 and 339 . In the postconstruction phase, the temperature $\left({ }^{\circ} \mathrm{C}\right.$ ) varied between 23.8 and 26.3 , the relative humidity of the air (R. H.\%) varied between 73 and 89.8 , while 

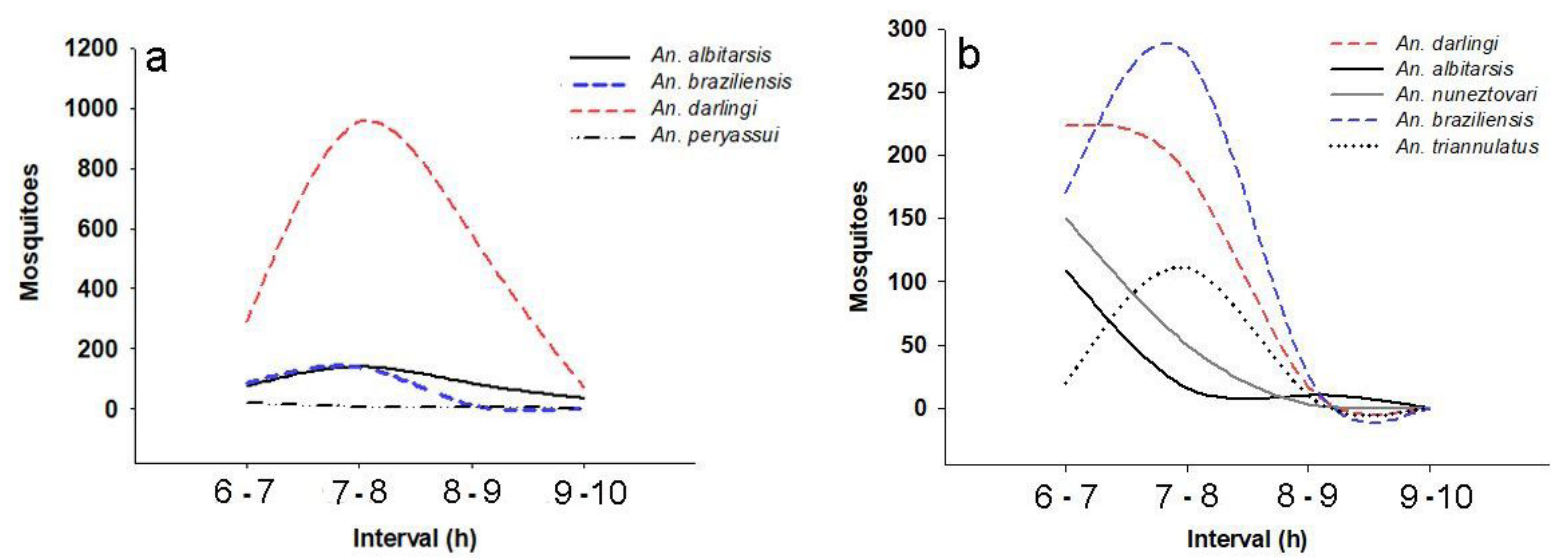

Figure 4 Hematophagic activity patterns of anophelines in the pre (a) and post-construction (b) phases of the Jirau hydroelectric plant, in Rondônia, Brazil.

the precipitation ( $\mathrm{mm}$ ) varied between 1.2 and 343.6. The fluviometric data $(\mathrm{cm})$ indicated that the river level of the Madeira River varied between 877 and 1451 in the pre-construction phase and between 836 and 1684, in the post-construction phase. It was observed that canonical analyzes 1 and 2 were the most informative in both phases, explaining $70.6 \%$ and $98.6 \%$ of the influence of environmental factors on Anopheles species, respectively (Figs. 5a, 5b). This analysis revealed that the An. peryassui, An. nuneztovari, An. darlingiand An. triannulatus showed to be correlated $\left(\mathrm{r}^{2}>0.5\right)$ with the relative humidity of the air (R. H\%), in the pre-construction phase. The last two were also correlated $\left(\mathrm{r}^{2}>0.5\right)$ with atmospheric temperature $\left({ }^{\circ} \mathrm{C}\right)$. The number of malaria cases was strongly correlated $\left(\mathrm{r}^{2}>0.6\right)$ with $A n$. darlingi, An. evansae and An. nuneztovari. The species An. darlingi, An. nuneztovari and An. triannulatus are also shown to be correlated with the river level at this stage (Fig. 5a).

In the post-construction phase, An. mattogrossensis, An. triannulatus and $A n$. evansae showed a correlation $\left(\mathrm{r}^{2}>0.5\right)$ with the river level. Only An. albitarsis correlated with atmospheric temperature $\left({ }^{\circ} \mathrm{C}\right)$, while An. braziliensis, An. minor and An. argyritarsis demonstrated positive correlation $\left(\mathrm{r}^{2}>0.4\right)$ with rainfall $\left(\mathrm{mm}^{3}\right)$. At this phase, the number of cases of malaria showed a positive correlation with An. oswaldoi $\left(r^{2}>0.5\right)$ (Fig. 5b). Although the number of cases of malaria did not correlate with An. darlingi in the post-construction phase, it is possible to observe in Fig. 6 that the density of this species is accompanied by the incidence of cases of malaria in both phases studied. According to data from SIVEP (Epidemiological Surveillance System/Ministry of Health of Brazil) in 2004, a total of 4.415 cases of malaria were reported, adding up to the total number of cases recorded in the locations of Abunã and Jaci Paraná. However, in 2018, 21 cases were reported in these same locations.

\section{Discussion}

Previous studies cite six species of anophelines frequently associated with malaria transmission in the Brazilian Amazon: An. albitarsis, An. aquasalis, An. braziliensis, 1908, An. darlingi, An. nuneztovari and An. triannulatus. Of these, only An. aquasalis was not obtained in this study because it is not endemic to the western Brazilian Amazon region (Tadei and Dutary-Thatcher, 2000; Alimi et al., 2015; Laporta et al., 2015; Bourke et al., 2018). It was observed that An. darlingi was the most abundant species in both phases analyzed (Table 1), corroborating the data obtained by Morais et al. (2012), Gil et al. (2015) and Rodrigues et al. (2017), when they investigated the anopheline fauna in Porto Velho (RO). Another species that also showed high abundance in both phases was An. braziliensis, corroborating with other studies carried out in the Amazon that also found a high abundance of this species (Barbosa et al., 2016).
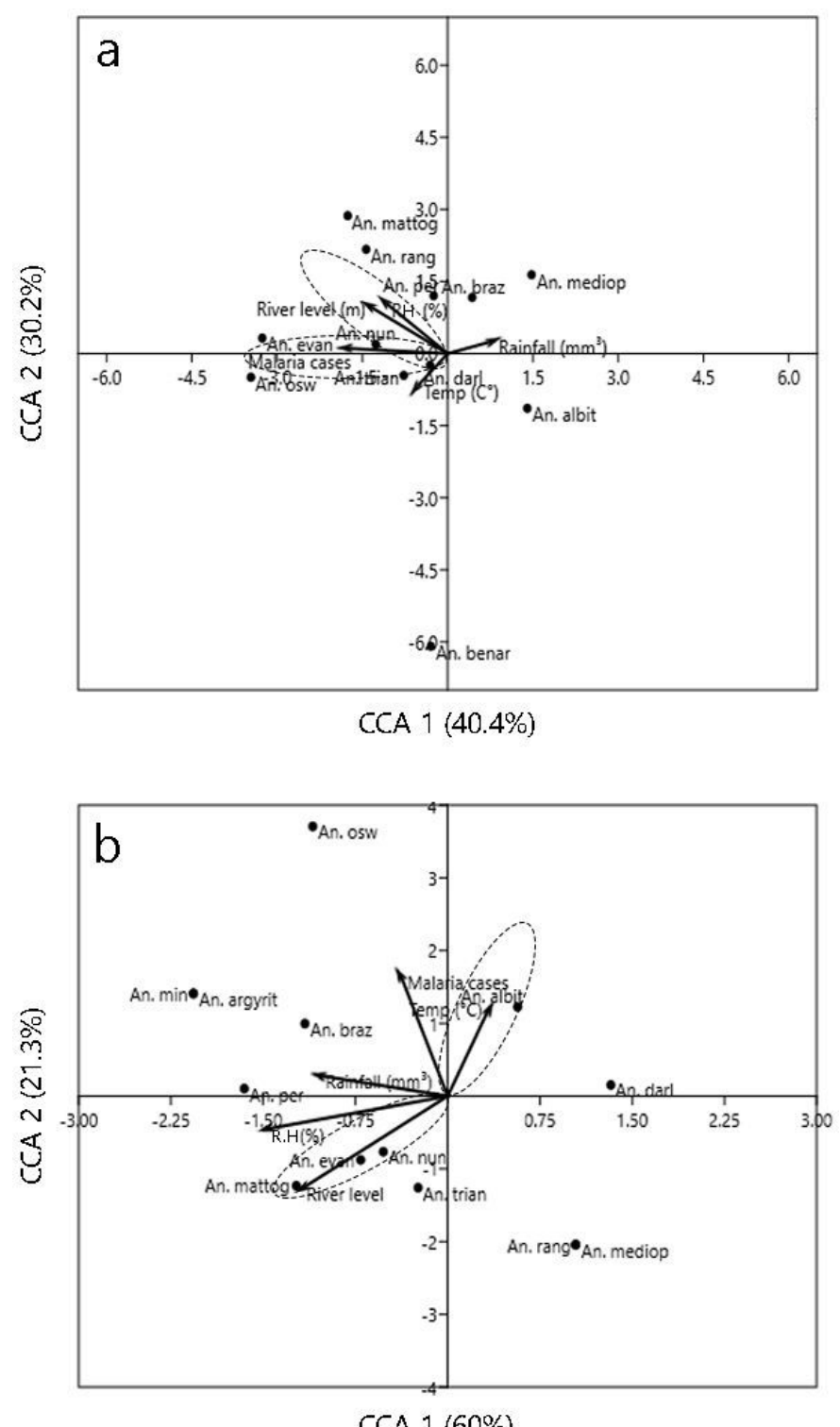

Figure 5 Canonical correlation analysis (CCA) ordering diagram between environmental factors and Anopheles species in the pre (a) and post-construction (b) phases of the Jirau hydroelectric plant: Relative Humidity of the air (R. H\%); Temp (Temperature

${ }^{\circ}$ C); Subtitle: Anopheles albit - An. albitarsis; Anopheles argyrit - An. argyritarsis; Anopheles benar - An. benarrochi; Anopheles braz - An. braziliensis; Anopheles darl An. darlingi; Anopheles evan - An. evansae; Anopheles mattog - An. mattogrossensis Anopheles mediop - An. mediopunctatus; Anopheles osw - An. oswaldoi; Anopheles per - An. peryassui; Anopheles rang - An. rangeli; Anopheles trian - An. triannulatus. 


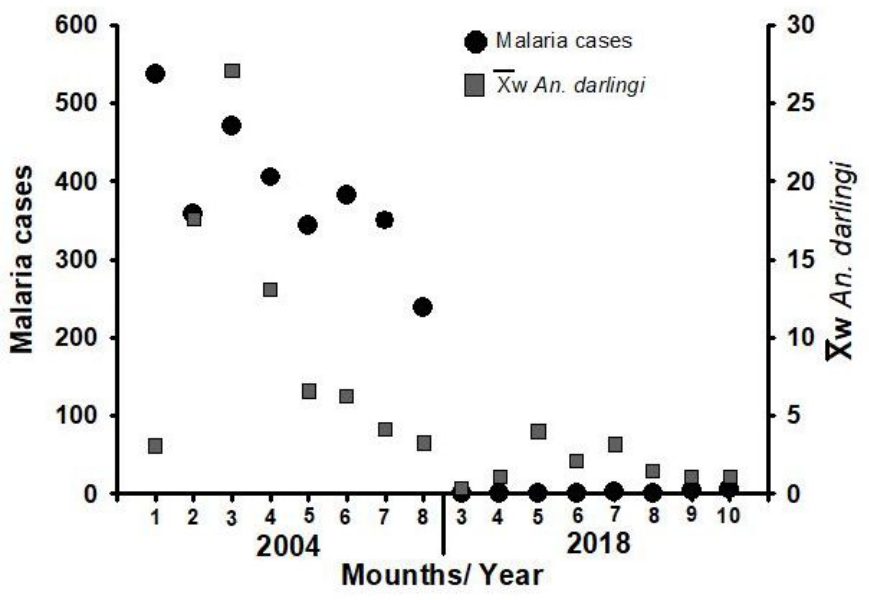

Figure 6 Cases of malaria and density of Anopheles darlingi in the area covered by the Jirau hydroelectric plant, in Rondônia, Brazil in the pre and post-construction phases. Source: SVS / SIVEP - Malaria.

Changes in the composition of anophelines fauna were observed between the pre and post-construction phases, such as the occurrence of An. benarrochicollected in the pre-construction phase and not collected in the post-construction phase. In addition, An. argyritarsis was only found after construction. According to Sallum et al. (1997), An. benarrochi was recorded in an area of intense agricultural activity related to sugar cane and pasture, so it is possible that the urbanization process that occurred in the area did not favor the permanence of this species in the environment.

Changes in the fauna composition were also observed in studies carried out in different stages of the construction of the Tucuruí hydroelectric plant, in the state of Pará (Tadei et al., 1998), highlighting the appearance of An. argyritarsis after the start of construction, a fact was also observed by Morais et al. (2012), evaluating the composition and richness of species in the coverage area of the Santo Antônio hydroelectric plant, in Rondônia. According to Silva et al. (2008), this species develops in artificial breeding sites and cohabits with Aedes albopictus (Skuse, 1894) in water tanks at ground level, showing itself adapted to anthropized environments. Therefore, it is possible that the environmental changes that occurred after the construction of the hydroelectric power plant favored the appearance of this species in the area.

According to the data obtained in this study, it was possible to observe the reduction in the abundance of An. darlingi in the postconstruction phase of the Jirau hydroelectric plant (Table 1; Figs. 2e, 2f). These data differ from those found by Rodrigues et al. (2017). The authors analyzed the abundance of An. darlingiin the peridomicile of residences present in the area covered by the same enterprise, where they did not observe a reduction in the abundance of this species, between 2011 and 2015. Nevertheless, differences in anopheline abundance have been reported by other authors in areas covered by hydroelectric projects during the post-construction phase. These results were also similar to those found by Rezende et al. (2009), who did not observe an evolution in the abundance of anophelines after the construction of the Rosal hydroelectric plant, in southeastern Brazil, the authors highlighted that the increase in breeding availability was accompanied by deforestation that led to the scarcity of food for females, once that wildlife fauna has been suppressed.

We believe that the reduction in the abundance of An. darlingiin the coverage area after the construction of the hydroelectric plant is due to the population explosion of Mansonia (Diptera: Culicidae) that occurred in the region, after the historic flooding of the Madeira River in 2014. It is known that the females of this group of mosquitoes are voracious, aggressive and compete with the anophelines for blood sources at the same times ( $6 \mathrm{pm}$ and $10 \mathrm{pm}$ ); in addition, these mosquitoes can still bite in the daytime as long as the environmental conditions are adequate (Forattini, 2002; Navarro-Silva et al., 2004). Another factor that may have contributed to this reduced number was the implementation of intense control strategies by the private sector, acting on the potential breeding sites of Anopheles and performing thermo-fogging in areas with high density of Mansonia mosquitoes.

The evaluated indices - diversity $\left(\mathrm{H}^{\prime}\right)$, richness (Sjack 1 ), dominance (d) and equitability $(J)$ did not show significant changes $(\mathrm{p}<0.05)$ between the pre and post-construction phases, which is possibly due to few variations in the composition of species obtained in this study. In the post-construction phase, dominance was alternated between An. braziliensis, An. albitarsis, An. nuneztovari and An. darlingi. According to Tadei et al. (2017), the dominance of An. darlingi in anthropized environments occurs due to the highly anthropophilic behavior of this species (Tadei et al., 1993).

In this study, the high anthropophilia of An. darlingi had a direct influence on its spatial distribution, which was high around Jaci Paraná (18.131 inhabitants) and Nova Mutum Paraná (6.575 inhabitants), locations with the highest demographic indexes in the studied region, according to IBGE (2019) (Figs. 2e, 2f). We point out that the points of greatest abundance of An. darlingi in the post-construction phase were in the vicinity of the hydroelectric plant, this occurred due to the increase in the demographic density around the enterprise for economic reasons (Fig. 2f). Therefore, the data reinforce the anthropophilic behavior of this species when compared to other anophelines (Deane, 1986), with a close relationship with humans in the environment. These observations also corroborate those found by Gil et al. (2015), in a study on the seasonal distribution of anophelines in the rural area of Porto Velho, which observed a high density of An. darlingi close to the points of greatest demographic densities.

The temporal distribution of An. darlingi observed in this study indicated that March was the month that presented the highest value of density ( ${ }^{\bar{x}} \mathrm{w}$ ), during the pre-construction phase (Fig. 3a). A bimodal pattern of temporal distribution was observed in the post-construction phase, with two density peaks: in May and June (Fig. 3b). These data corroborate those found by Gil et al. (2015), these authors evaluated the seasonal distribution of anophelines in the rural area of Porto Velho and observed the occurrence of three peaks of An. darlingi, the first and second in March and May (end of the rainy season) and the third between August and September (end of dry season). The authors pointed out that after the construction of hydroelectric projects in the region, this third peak occurred in July.

In the Brazilian Amazon, the temporal distribution of anophelines populations varies according to the region due to the extensive territorial area and the high diversity of habitats that make up the biome. In the state of Amapá, located in the eastern Amazon, Barbosa et al. (2014) observed the unimodal temporal distribution of An. darlingi, differing from the data obtained in this study. The unimodal pattern of temporal distribution was also observed by Tadei and Dutary-Thatcher (2000), studying the anophelines in 15 locations in the Brazilian Amazon. They observed that on the AM 352 highway and in the municipality of Novo Airão (state of Amazonas), An. darlingi was more frequent in the month of June, that is, in the transition between the rainy and dry periods.

The most frequent species in the pre and post-construction phases of the Jirau hydroelectric plant showed a decrease in density in August, the hottest month of the year (Figs. 3a, 3b). This may be associated with a reduction in the availability of temporary breeding sites due to the low levels of precipitation and high temperatures, as a result of which there is a reduction in the population density of these mosquitoes and also in the transmission of malaria. According to Wolfarth-Couto et al. $(2019,2020)$, malaria cases are strongly correlated with rainfall and river levels, these factors increase the availability of breeding sites, in greater numbers in the rainy season and scarce at the height of the drought. 
Concerning the pattern of hematophagic activity of the species, the first two hours after dark were preferred in both phases analyzed. Variation in the hematophagic activity of the species was observed between the pre-construction (from 7:00 pm to 8:00 pm) and post-construction (from 6:00 pm to 7:00 pm) phases (Figs. 4a, 4b), corroborating with the data observed by Tadei et al. (1998), who evaluated the activity of biting in four locations in the Amazon, where they observed that in three, including themunicipality of Ariquemes, the time between 6:00 pm and 7:00 pm was the one with the greatest hematophagic activity of the females of An. darlingi, An. nuneztovari, An. oswaldoi, An. triannulatus, An. albitarsis and An. braziliensis. The change observed in the pattern of hematophagic activity of the species in this study corroborates the data found by Gomes et al. (2010), who observed differences in the pattern of hematophagic activity of Anopheles species after the implantation of the hydroelectric plant in the Paraná River. These authors also emphasize that these changes occurred due to the ecological changes that took place after the filling of the dam.

Malaria cases showed a positive correlation with An. darlingi, in the pre-construction phase and with An. oswaldois.l in the post-construction $\left(\mathrm{r}^{2}>0.5\right)$ (Figs. $\left.5 \mathrm{a}, 5 \mathrm{~b}\right)$. In this study, the high density of An. darlingi in the pre-construction phase coincides with the high number of malaria cases in 2004 in Jaci Paraná and Abunã, just as the drop in density of An. darlingicoincides with the reduced number of malaria cases in 2018, in the same locations, although the statistical analysis does not indicate a correlation, possibly due to the low number of registered cases (Fig. 6). In the post-construction phase, the number of malaria cases correlated with An. oswaldoi s.l. According to the data found by Branquinho et al. (1996) in Acre, this species was found naturally infected by Plasmodium vivax Grassi and Feletti, 1890, Plasmodium vivaxV247, Plasmodium falcipaum Welch, 1897, Plasmodium malariae Laveran, 1881, thus, it was considered the main vector of malaria in that region. Later, studies carried out by Marrelli et al. (1998, 1999), also investigated the susceptibility of this species and highlighted the relationship of this species with $P$. vivax in locations in the states of Acre and Rondônia.

According to Tadei et al. (1998), the peak density of An. darlingi is directly correlated with the period of greatest malaria transmission in the Amazon. Considering the environmental variables, a strong correlation was observed between An. darlingiand relative humidity of the air $(\mathrm{R} . \mathrm{H} \%)\left(\mathrm{r}^{2}>0.5\right)$, differing from the data found by Barbosa et al. (2014), where this species showed no correlation with temperature and humidity, in a study on the composition and temporal variation of anophelines, in the state of Macapá, northern Brazil.

Several factors may have contributed to the decrease the cases of malaria between the pre and post-construction phases, in the area covered by the Jirau hydroelectric plant (Fig. 6). According to Padilha et al. (2019), this reduction can be attributed to socio-economic factors and loss of available habitats for deep-forest vectors (Laporta, 2019) as a result of deforestation in the region in recent years. In addition, we also emphasize the implementation of vector control actions by the government and also by the private sector through the Public Health Program for Energia Sustentável do Brasil - ESBR, related to the development of the following activities: a) vector control - application of adulticides, biolarvicides, installation of long-lasting impregnated mosquito nets; b) early diagnosis; c) identification of asymptomatic and d) education and health activities workshops and lectures for the local population. These activities, together with the inspection of the public authorities, have a decisive role in malaria control in the area covered by the Jirau hydroelectric plant.

\section{Conclusions}

According to the results obtained in this study, the construction of the hydroelectric plant had little influence on the composition of anopheline species where it was possible to observe small changes. However, we emphasize the changes were observed in the relative abundance, in the spatio-temporal distribution and in the pattern of hematophagic activity of the species that directly influenced the dynamics of malaria in the region.

\section{Acknowledgments}

The authors would like to thank the Coordenação de Aperfeiçoamento de Pessoal de Nível Superior - CAPES (Code 001) for the scholarship granted to the first author. We thank FAPEAM-Programa POSGRAD for the support in the activities of Programa de Pós-Graduação em Ciências Biológicas (Entomologia) of Instituto Nacional de Pesquisas da Amazônia - INPA. We also thank the server MSc Carlos Alberto Praia for the identification of the specimens, in addition to the servers Elias Rebouças, Acilino Carvalho de Souza and Antônio Francisco for the collection of mosquitoes in the field. We also thank FURNAS and ESBR (Energia Sustentável do Brasil) for making it possible to carry out mosquito samplings activities in 2004 and 2018, respectively.

\section{Conflicts of interest}

The authors declare no conflicts of interest.

\section{Author contribution statement}

FASF and WPT contributed with experimental design, data analysis and manuscript writing; GRL and TMB contributed with the organism identification and data analysis; FMC, RAR, VMS, VF and VASN contributed with data analysis and manuscript review.

\section{References}

Alimi, T. O., Fuller, D. O., Qualls, W. A., Herrera, S. V., Arevalo-Herrera, M., Quinones, M. L., Lacerda, M. V. G., Beier, J. C., 2015. Predicting potential ranges of primary malaria vector and malaria in northern South America basead on projected changes in climate, land cover and human population. Parasit. Vectors 8 (1), 431. http://dx.doi. org/10.1186/s13071-015-1033-9.

Arcos, A. N., Ferreira, F. A. S., Cunha, H. B., Tadei, W. P., 2018. Characterization of artificial larval habitats of Anopheles darlingi(Diptera: Culicidae) in the Brazilian Central Amazon. Rev. Bras. Entomol. 62 (4), 267-274. http://dx.doi.org/10.1016/j.rbe.2018.07.006.

Barbosa, L. M. C., Souto, R. N. P., dos Anjos Ferreira, R. M., Scarpassa, V. M., 2016. Behavioral patterns, parity rate and natural infection analysis in anopheline species involved in the transmission of malaria in the northeastern Brazilian Amazon region. Acta Trop. 164, 216-225. http://dx.doi.org/10.1016/j.actatropica.2016.09.018.

Barbosa, L. M. C., Souto, R. N. P., Ferreira, R. M. D. A., Scarpassa, V. M., 2014. Composition, abundance and aspects of temporal variation in the distribution of Anopheles species in an area of Eastern Amazonia. Rev. Soc. Bras. Med. Trop. 47 (3), 313-320. http://dx.doi. org/10.1590/0037-8682-0239-2013.

Barreto, M. L., Teixeira, M. G., Bastos, F. I., Ximenes, R. A., Barata, R. B., Rodrigues, L. C., 2011. Successes and failures in the control of infectious diseases in Brazil: social and environmental context, policies, interventions, and research needs. Lancet 377 (9780), 1877-1889. http://dx.doi.org/10.1016/S0140-6736(11)60202-X.

Bourke, P. B., Conn, J. E., Oliveira, T. M. P., Chaves, L. S. M., Bergo, E. S., Laporta, G. Z., Sallum, M. A. M., 2018. Exploring malaria vector 
diversity on the Amazon Frontier. Malar. J. 17 (1), 342. http://dx.doi. org/10.1186/s12936-018-2483-2.

Branquinho, M. S., Araujo, M. S., Natal, D., Marrelli, M. T., Rocha, R. M., Taveira, F. A., Kloetzel, J. K., 1996. Anopheles oswaldoi a potential malaria vector in Acre, Brazil. Trans. R. Soc. Trop. Med. Hyg. 90 (3), 233. http://dx.doi.org/10.1016/S0035-9203(96)90225-4.

Chaves, L. S. M., Fry, J., Malik, A., Geschke, A., Sallum, M. A. M., Lenzen, M., 2020. Global consumption and international trade in deforestationassociated commodities could influence malária risk. Nat. Commun. Arcos 11, 1258.

Consoli, R. A. G. B., Lourenço-de-Oliveira, R., 1994. Principais mosquitos de importância sanitária no Brasil. Fiocruz, Rio de Janeiro.

Couto, R. C. S., 1999. Saúde e Projetos de Desenvolvimento na Amazônia: a caso das hidrelétricas. Novos Cad. Naea 2 (2), 205-216.

Cruz, R. M. B., Gil, L. H. S., Silva, A. A., Araújo, M. S., Katsuragawa, T. H., 2009. Mosquito abundance and behavior in the influence area of the hydroeletric complex on the Madeira River, Western Amazon, Brazil. Trans. R. Soc. Trop. Med. Hyg. 103 (11), 1174-1176. http:// dx.doi.org/10.1016/j.trstmh.2008.09.007.

Deane, L. M., 1986. Malaria vectors in Brazil. Mem. Inst. Oswaldo Cruz 81 (Suppl.2), 5-14. http://dx.doi.org/10.1590/S0074-02761986000600002.

Energia Sustentável do Brasil - ESBR, 2020. Características da UHE Jirau. Available in: https://www.esbr.com.br/a-usina (accessed 6 March 2020).

Faran, M. E., Lintichum, K. J., 1981. A handbook of the Amazonian species of Anopheles (Nyssorhynchus) (Diptera: Culicidae). Mosq. Syst. 13, 1-81.

Fearnside, P. M., 1999. Impactos sociais da barragem de Tucuruí. In: Henry, R. (Ed.), Ecologia de reservatórios: estrutura, função e aspectos sociais. Universidade Estadual Paulista, Botucatu, SP, pp. 219-244.

Fearnside, P. M., 2001. Environmental impacts of Brazil's Tucuruí Dam: unlearned lessons for hydroelectric development in Amazonia. Environ. Manage. 27 (3), 377-396. http://dx.doi.org/10.1007/ s002670010156.

Fearnside, P. M., 2015. Hidrelétricas na Amazônia: impactos ambientais e sociais na tomada de decisões sobre grandes obras. Editora do INPA, Manaus.

Ferreira, F. A. S., Arcos, A. N., Sampaio, R. T. M., Rodrigues, I. B., Tadei, W. P., 2015. Effects of Bacillus sphaericus Neide on Anopheles (Diptera: Culicidae) and associated insect fauna in fish ponds in the Amazon. Rev. Bras. Entomol. 59 (3), 234-239. http://dx.doi. org/10.1016/j.rbe.2015.03.013.

Ferreira, M. U., Castro, M., 2016. Challenges for malaria elimination in Brazil. Malar. J. 15 (1), 284. http://dx.doi.org/10.1186/s12936016-1335-1.

Forattini, O. P., 2002. Culicidologia médica. Vol. 2. EDUSP, São Paulo.

Gil, L. H. S., Rodrigues, M. S., Lima, A. A., Katsuragawa, T. H., 2015. Seasonal distribution of malaria vectors (Diptera: Culicidae) in natural localities of Porto Velho, Rondônia, brazilian amazon. Rev. Inst. Med. Trop. São Paulo 57 (3), 263-267. http://dx.doi.org/10.1590/ S0036-46652015000300014.

Goham, J. R., Stojanovick, C. J., Scott, H. G., 1967. Clave ilustrada para los mosquitos anofelinos de Sudamérica Oriental. U. S. Department of Health, Education \& Welfare. Washington DC.

Gomes, A. C., Paula, M. B., Natal, D., Gotlieb, S. L. D., Mucci, L. F., 2010. Effects of flooding of the River Paraná on the temporal activity of Anopheles (Nyssorhynchus) darlingi Root (Diptera: Culicidae), at the border State of Mato Grosso do Sul and São Paulo, Brazil. Rev. Soc. Bras. Med. Trop. 43 (5), 516-522. http://dx.doi.org/10.1590/ S0037-86822010000500009.

Guimarães, A. É., Gentile, C., Alencar, J., Lopes, C. M., Mello, R. P. D., 2004. Ecology of Anopheline (Diptera, Culicidae), malaria vectors around the Serra da Mesa Reservoir, State of Goiás, Brazil: 1-Frequency and climatic factors. Cad. Saude Publica 20 (1), 291-302. http://dx.doi. org/10.1590/S0102-311X2004000100047.

Instituto Brasileiro de Geografia e Estatística - IBGE, 2019. Diretoria de Pesquisas, Coordenação de População e Indicadores Sociais, Estimativas da população residente com data de referência $1^{\circ}$ de julho de 2019. Brasília. Available in: https://cidades.ibge.gov.br/ brasil/ro/porto-velho/panorama (accessed 13 April 2020).

Junk, W. J., Nunes de Mello, J. A. S., 1987. Impactos ecológicos das represas hidrelétricas na bacia Amazônica Brasileira. Tüb. Geogr. Stud. 95, 367-385.

Junk, W. J., Nunes de Mello, J. A. S., 1990. Impactos ecológicos das represas hidrelétricas na bacia amazônica brasileira. Estud. Av. 4 (8), 126-143. http://dx.doi.org/10.1590/S0103-40141990000100010. Katsuragawa, T. H., Cunha, R. P. A., Souza, D. C. A., Gil, L. H. S., Cruz, R. B., Silva, A. A., Tada, M. S., Silva, L. H. P., 2009. Malária e aspectos hematológicos em moradores da área de influência dos futuros reservatórios das hidrelétricas de Santo Antônio e Jirau, Rondônia, Brasil. Cad. Saude Publica 25 (7), 1486-1492. http://dx.doi.org/10.1590/ S0102-311X2009000700006.

Laporta, G. Z., 2019. Amazonian rainforest loss and declining malaria burden in Brazil. Lancet Planet. Health 3 (1), e4-e5. http://dx.doi. org/10.1016/S2542-5196(18)30243-2.

Laporta, G. Z., Linton, Y.-M., Wilkerson, R. C., Bergo, E. S., Nagaki, S. S., Sant'Ana, D. C., Sallum, M. A. M., 2015. Malaria vectors in South America: current and future scenarios. Parasit. Vectors 8 (1), 426. http://dx.doi.org/10.1186/s13071-015-1038-4.

Li, K., Lin, B., 2015. Impacts of urbanization and industrialization on energy consumption/CO2 emissions: does the level of development matter? Renew. Sustain. Energy Rev. 52, 1107-1122. http://dx.doi. org/10.1016/j.rser.2015.07.185.

Marrelli, M. T., Branquinho, M. S., Hoffmann, H. E., Taipe-Lagos, C. B., Natal, D., Kloetzel, J. K., 1998. Correlation between positive serology for Plasmodium vivax-like/Plasmodium simiovale malaria parasites in the human and anopheline population in the state of Acre, Brazil. Trans. R. Soc. Trop. Med. Hyg. 92 (2), 149-151. http://dx.doi. org/10.1016/S0035-9203(98)90723-4.

Marrelli, M. T., Honório, N. A., Flores-Mendoza, C., Lourenço-de-Oliveira, R., Marinotti, O., Kloetzel, J. K., 1999. Comparative susceptibility of two members of the Anopheles oswaldoi complex, An. oswaldoi and An. konderi, to infection by Plasmodium vivax. Trans. R. Soc. Trop. Med. Hyg. 93 (4), 381-384. http://dx.doi.org/10.1016/S00359203(99)90123-2.

Ministério da Saúde - MS, 2003. Programa Nacional de Prevenção e Controle da Malária - PNCM. Brasília. Available in: http://bvsms. saude.gov.br/bvs/publicacoes/programa_nac_prev_malaria.pdf (accessed 18 October 2020)

Ministério da Saúde - MS, 2006. Portaria Ministerial no 47, de 29 de dezembro de 2006. Revogada. Diário Oficial da União, Brasília.

Ministério da Saúde - MS, 2014. Portaria Ministerial nº 1, de 13 de janeiro de 2014. Diário Oficial da União, Brasília.

Ministério da Saúde - MS, 2019. Vigilância em saúde no Brasil 2003/2019: da criação da Secretaria de Vigilância em Saúde aos dias atuais. Bol. Epidemiol. 50 (n. esp.), 1-154. Available in: http://www.saude.gov. br/boletins-epidemiologicos (accessed 13 June 2020).

Morais, S. A., Urbinatti, P. R., Sallum, M. A. M., Kuniy, A. A., Moresco, G. G., Fernandes, A., Nagaki, S. S., Natal, D., 2012. Brazilian mosquito (Diptera: Culicidae) fauna. I. Anopheles species from Porto Velho, Rondônia state, western Amazon, Brazil. Rev. Inst. Med. Trop. São Paulo 54 (6), 331-335. http://dx.doi.org/10.1590/S003646652012000600008. 
Navarro-Silva, M. A., Barbosa, A. A., Calado, D., 2004. Atividade de Mansonia spp. (Mansoniini, Culicidae) em fragmento florestal na área urbana de Curitiba, Paraná, Brasil. Rev. Bras. Zool. 21 (2), 243-247. http://dx.doi.org/10.1590/S0101-81752004000200012.

Odinetz-Collart, O., 1987. La pêche crevettière de Macrobrachium amazonicum (Palaemonidae) dans Le Bas-Tocantins après la fermeture du barrage de Tucuruí (Brésil). Rev. Hydrobiol. Trop. 20 (2), 131-144.

Oliveira-Ferreira, J., Lacerda, M. V. G., Brasil, P., Ladislau, J. L. B., Tauil, P. L., Daniel-Ribeiro, C. T., 2010. Malaria in Brazil: an overview. Malar. J. 9 (1), 115. http://dx.doi.org/10.1186/1475-2875-9-115.

Osório-Quintero, L., Dutary-Thatcher, B., Tadei, W. P., 1996. Ocorrência de espécies de Anopheles e outros culicídeos na área de influência da hidrelétrica de Balbina: cinco anos após o enchimento do reservatório. Acta Amazon. 26 (4), 281-296. http://dx.doi.org/10.1590/180943921996264296.

Padilha, M. A. O., Melo, J. O., Romano, G., Lima, M. V. M., Alonso, W. J., Sallum, M. A. M., Laporta, G. Z., 2019. Comparison of malária incidence rates and socioeconomic-environmental factors between the states of Acre and Rondônia: a spatial-temporal modelling study. Malar.J. 18 (1), 306. http://dx.doi.org/10.1186/s12936-019-2938-0.

Paula, M. B., Gomes, A. C., 2007. Culicidae (Diptera) em área sob influência de construção de represa no estado de São Paulo. Rev. Saude Publica 41 (2), 284-289. http://dx.doi.org/10.1590/S0034-89102006005000018.

Paula, M. B., Gomes, A. C., Natal, D., Duarte, A. M. R. C., Mucci, L. F., 2012. Effects of artificial flooding for hydroelectric development on the population of Mansonia humeralis (Diptera: Culicidae) in the Paraná River, São Paulo, Brazil. J. Trop. Med. 2012, 598789. https:// doi.org/10.1155/2012/598789.

Pires, E. P., Ramos, E. M. L. S., Martins, E., Silva, H. P., 2019. The Belo Monte hydroelectric plant and the epidemiological profile of malaria in the population of Altamira city- Pará -Brazil. Int. J. Dev. Res. 9 (1), 24982-24985.

Rêgo, F. D., Oliveira, M. A., Carvalho, G. M. L., Andrade Filho, J. D., 2020. Biodiversity of Hematophagous Diptera (Culicidae and Psychodidae) in a Small Hydroelectric Power Station and Surrounding Area in the State of Minas Gerais, Brazil. J. Med. Entomol. 57 (1), 312-317. http://dx.doi.org/10.1093/jme/tjz144.

Rezende, H. R., Sessa, P. A., Ferreira, A. L., Santos, C. B., Leite, G. R., Falqueto, A., 2009. Efeitos da implantação da Usina Hidrelétrica de Rosal, Rio Itabapoana, Estados do Espírito Santo e Rio de Janeiro, sobre anofelinos, planorbídeos e flebotomíneos. Rev. Soc. Bras. Med. Trop. 42 (2), 160-164. http://dx.doi.org/10.1590/S003786822009000200013.

Rodrigues, M. S., Batista, E. P., Silva, A. A., Costa, F. M., Neto, V. S., Gil, L. H. S., 2017. Change in Anopheles richness and composition in response to artificial flooding during the creation of the Jirau hydroeletric dam in Porto Velho, Brazil. Malar. J. 16 (1), 87. http:// dx.doi.org/10.1186/s12936-017-1738-7.

Rodrigues, W. C., 2017. Dominância de Simpson. DivEs - Diversidade de Espécies v.4.0 (AntSoft Systems On Demand) - Guia do usuário. Available in: http://dives.ebras.bio.br (accessed 13 June 2020).

Sadorsky, P., 2013. Do urbanization and industrialization affect energy intensity in developing countries? Energy Econ. 37, 52-59. http:// dx.doi.org/10.1016/j.eneco.2013.01.009.

Sallum, M. A. M., Bergo, E. S., Forattini, O. P., 1997. First record of Anopheles benarrochi Gabaldon, Cova Garcia \& Lopes from the state of São Paulo, Southern Brazil. Mem. Inst. Oswaldo Cruz 92 (2), 233-234. http://dx.doi.org/10.1590/S0074-02761997000200016.

Sallum, M. A. M., Obando, R. G., Carrejo, N., Wilkerson, R. C., 2020. Identification keys to the Anopheles mosquitoes of South America (Diptera: culicidae). Introduction. Parasit. Vectors. 13 (1), 583. http:// dx.doi.org/10.1186/s13071-020-04298-6.
Sanchez-Ribas, J., Parra-Henao, G., Guimarães, A., 2012. Impact of dams and irrigation schemes in Anophelinae (Diptera: Culicidae) bionomics and malaria epidemiology. Rev. Inst. Med. Trop. São Paulo 54 (4), 179-191. http://dx.doi.org/10.1590/S0036-46652012000400001.

Secretaria Municipal de Saúde de Porto Velho - SEMUSA-PMPV, 2017. Boletim da Saúde, 6. ed. SEMUSA/ESBR. 39 pp. Available in: https:// www.esbr.com.br/uploads/document/file/1128/6_Boletim-daSau\%CC\%81de-02_sem_marca_de_corte.pdf(accessed 13 April 2020).

Silva, J. D. S., Pacheco, J. B., Alencar, J., Guimarães, A. É., 2010. Biodiversity and influence of climatic factors on mosquitoes (Diptera: Culicidae) around the Peixe Angical hydroelectric scheme in the state of Tocantins, Brazil. Mem. Inst. Oswaldo Cruz 105 (2), 155-162. http:// dx.doi.org/10.1590/S0074-02762010000200008.

Silva, J. S., Acel, A. M., Guimarães, A. É., Alencar, J., 2008. Anopheles (Nyssorhynchus) argyritarsis larvae found in artificial breeding sites in the State of Mato Grosso. Rev. Soc. Bras. Med. Trop. 41 (3), 313-314. http://dx.doi.org/10.1590/S0037-86822008000300019.

Tadei, W. P., Mascarenhas, B. M., Podestá, M. G., 1983. Biologia de anofelinos amazônicos VIII. Conhecimentos sobre a distribuição de espécies de Anopheles na região de Tucuruí-Marabá (Pará). Acta Amazon. 13 (1), 103-140. http://dx.doi.org/10.1590/1809-43921983131103.

Tadei, W. P., Santos, J. M. M., Costa, W. L. S., Scarpassa, V. M., 1988. Biologia de anofelinos amazônicos. XII. Ocorrência de espécies de Anopheles, dinâmica da transmissão e controle da malária na zona urbana de Ariquemes (Rondônia). Rev. Inst. Med. Trop. São Paulo 30 (3), 221-251. http://dx.doi.org/10.1590/S0036-46651988000300017.

Tadei, W. P., Santos, J. M. M., Scarpassa, V. M., Rodrigues, I. B., 1993. Incidence, distribution and ecological aspects of Anopheles species (Diptera: Culicidae), in: natural and environmental impact areas of Brazilian Amazon. In: Ferreira, E.J.G., Santos, G.M., Leão, E.L.M., Oliveira, L.A.(Eds.), Scientific Bases for Development and Preservation Strategies of the Amazon. Vol. 2. Instituto Nacional de Pesquisas da Amazônia, Manaus, pp. 167-196.

Tadei, W. P., Scarpassa, V. M., Thatcher, B. D., Santos, J. M., Rafael, M. S., Rodrigues, I. B., 1998. Ecologic observations on Anophelinae vectors of malaria in the brazilian Amazon. Am. J. Trop. Med. Hyg. 59 (2), 325-335. http://dx.doi.org/10.4269/ajtmh.1998.59.325.

Tadei, W. P., Dutary-Thatcher, B., 2000. Malaria vectors in the Brazilian Amazon: Anopheles of the subgenus Nyssorhynchus. Rev. Inst. Med. Trop. São Paulo 42 (2), 87-94. https://doi.org/10.1590/S003646652000000200005.

Tadei, W. P., Rodrigues, I. B., Rafael, M. S., Sampaio, R. T. M., Mesquita, H. G., Pinheiro, V. C. S., Zequi, J. A. C., Roque, R. A., Santos, J. M. M., 2017. Adaptative process, control measures, genetic background, and resilience of malaria vectors and environmental changes in the Amazon region. Hydrobiologia 789 (1), 179-196. http://dx.doi. org/10.1007/s10750-016-2960-y.

Tolmasquim, M. T., 2016. Energia renovável: hidráulica, biomassa, eólica, solar, oceânica. EPE, Rio de Janeiro.

von Sperling, E., 2012. Hydropower in Brazil: overview of positive and negative environmental aspects. Energy Procedia 18, 110-118. http:// dx.doi.org/10.1016/j.egypro.2012.05.023.

Wolfarth-Couto, B., Filizola, N., Durieux, L., 2020. Seasonal pattern of malaria cases and the relationship with hydrologyc variability in the Amazon State, Brazil. Rev. Bras. Epidemiol. 23, e200018. http:// dx.doi.org/10.1590/1980-549720200018.

Wolfarth-Couto, B., Silva, R. A., Filizola, N., 2019. Variability in malaria cases and the association with rainfall and rivers water levels in Amazon State, Brazil. Cad. Saude Publica 35 (2), e00020218. http:// dx.doi.org/10.1590/0102-311x00020218.

World Health Organization - WHO, 2019. World Malaria Report. Geneva. 